\title{
Bacterial Contamination of Cellular Phones: Are Mobile Phones Safer than Smart Phones?
}

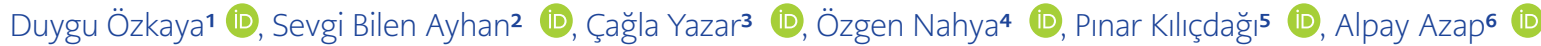 \\ 1 University of Health Sciences, Gülhane Research and Educational Hospital, istanbul Turkey \\ 2 University of Health Sciences, Dışkapı YIldırım Beyazıt Research and Educational Hospital, Ankara, Turkey \\ 3 Başkent University Hospital, Ankara, Turkey \\ 4 Department of Clinical Microbiology and Infectious Diseases, University of Health Sciences, Tepecik Research and Educational \\ Hospital, izmir, Turkey \\ ${ }^{5}$ Children's Hospital, Ankara City Hospital, Bilkent, Ankara \\ 6 Department of Clinical Microbiology and Infectious Diseases, Ankara University School of Medicine, Ankara, Turkey
}

\begin{abstract}
Objective: We aimed to describe pathogenic contamination on healthcare workers' cellular phones, detect factors associated with contamination, and demonstrate whether there was a link between cell phone contamination and subsequent healthcare-associated infections. Methods: The study was conducted in a 2000-bed tertiary care university hospital in Ankara. A total of 631 healthcare workers (HCWs) from several departments willing to participate were included in the study. Bacterial cultures were taken from each cell phone via rotating a sterile swab moistened with sterile physiological saline solution over both sides of the phone surface and cover. Samples were taken to the bacteriology laboratory within one hour and streaked onto $5 \%$ sheep blood agar. Isolated microorganisms were identified with conventional methods.

Results: All 631 cell phones investigated had positive cultures; forty-four $(6.05 \%)$ were pathogenic microorganisms. Drug resistance was not detected among pathogenic bacteria. As determined by univariate analysis, using flip phone cover $(\mathrm{P}=0.022)$, a professional experience of fewer than five years $(\mathrm{P}=0.049$ ), having cleaned the phone within the last 48 hours $(P=0.030)$, and working in a medical ward $(P=0.022)$ were significantly associated with pathogen contamination on the devices. Multivariate analysis with logistic regression revealed that using flip cover is the only factor associated with pathogen contamination on cell phones $(\mathrm{P}=0.035)$. Pathogen contamination on smartphones $(7.7 \%)$ seemed to be higher than on mobile phones (5.2\%) ( $\mathrm{P}=0.263)$.

Conclusion: Pathogen contamination on smartphones was higher than on mobile phones but did not reach statistical significance. Using flip cover covers on cellular phones increases contamination rates. We could not show any HAI occurred by the bacteria isolated from cell phones, but health care workers should pay attention to this issue.
\end{abstract}

Keywords: bacterial contamination, mobile phones, Healthcare Associated Infections
Corresponding Author:

Alpay Azap

\section{E-mail:}

azap@medicine.ankara.edu.tr

Received: December 14, 2020 Accepted: December 24, 2020 Published: December 31, 2020

\section{Suggested citation:}

Özkaya D, Bilen Ayhan S, Yazar Ç, Nahya Ö, Kılıçdağı P, Azap

A. Bacterial Contamination of Cellular Phones: Are Mobile Phones Safer than Smart Phones? Infect Dis Clin Microbiol 2020; 3: 147-152.

DOI: $10.36519 / \mathrm{idcm} .2020 .0032$ 


\section{BACKGROUND}

$\mathrm{H}$ ealthcare-associated infections (HAIs) are infections, which are not present at admission or might be in incubating, are acquired in the hospital (1). HAIs remain a major problem for they increase not only morbidity and mortality but also costs for health care systems. According to the recent report by the Centers for Disease Prevention and Control (CDC), about 1 in 25 U.S. hospital patients is diagnosed with at least one infection related to hospital care, with additional infections occurring in other healthcare settings (2).

Medical devices may spread infection in clinical settings (1). Devices like catheters or ventilators used in medical procedures can be contaminated by health care workers (HCWs) who have handled their cellular phones (3-8). Cellular phones used by surgical teams in operating rooms have been reported to carry pathogens and may serve as reservoirs for pathogens (4). Several viral pathogens (Respiratory Syncytial Virus, Adenovirus and Influenza Virus) have been reported in $10 \%$ of the sampled phones used by HCWs in a pilot study from Israel (5). Though pathogens may be passed by HCWs who use cellular phones, no clear association between contamination of cell phones and HAIs has been established.

This study aimed to investigate pathogenic contamination on healthcare workers' cellular phones, detect factors associated with

\section{HIGHLIGHTS}

- All cellular phones included in the study ( $\mathrm{N}=631$ ) were contaminated with bacteria of which 44 (6\%) were pathogenic, but not resistant to antibiotics.

- Pathogen contamination on smartphones seemed to be higher compared to mobile phones but did not reach to statistical significance.

- Using two-sided covers on cellular phones increases contamination rates, so banning these types of covers may prevent HCWs from passing infections to patients in hospital settings. contamination, and demonstrate whether there was a link between cell phone contamination and subsequent HAIs.

\section{MATERIALS AND METHODS}

\section{Setting}

The study was conducted in a 2000-bed tertiary care university hospital in Ankara, Turkey. All HCWs in the hospital were invited to attend the study. A total of 631 HCWs from several departments willing to participate were included in the study (Table 1). This study was approved by Ankara University's Committee of Research, Ethics and Deontology.

\section{Data Collection}

During study period (three weeks), bacterial cultures were taken from each cell phone. A sterile swab moistened with sterile physiological saline solution was rotated over both sides of the phone surface and cover. Obtained samples were taken to the bacteriology laboratory within one hour and streaked onto 5\% sheep blood agar. Isolated microorganisms were categorized as Gramnegative or -positive by using Gram stain. Gramnegative microorganisms were identified with conventional biochemical methods (Three Sugar Iron, Indole Motility Urease, and oxidase tests) and Gram-positive microorganisms were identified with catalase and coagulase tests. Bacteria constituting skin flora (such as coagulase-negative staphylococci, Corynebacterium spp., alpha-hemolytic streptococci) were considered non-pathogenic, while bacteria other than skin flora elements were considered pathogenic. Antimicrobial susceptibility testing for pathogen bacteria was performed by disc diffusion method based on The Clinical \& Laboratory Standards Institute (CLSI) guideline.

A questionnaire was performed on HCWs to collect personal information such as age, gender, occupation and current employment unit. The type of cell phone, frequency and reasons (phone call, message, social media, game, taking photo/video) for use, frequency and method of cleaning, cover, and carbon film usage were also asked in the questionnaire.

Cellular phones with a touch screen are defined as 
smartphones, while phones without a touch screen are defined as mobile phones.

\section{Statistical Analysis}

Data obtained from laboratory and questionnaire were analysed via a statistical software programme (STATA 9.0, TexasUSA). Chi-square test and Student's t-test were performed to compare categorical and continuous variables, respectively. Univariate analyses were followed by logistic regression for parameters that were determined as statistically significant. Statistical significance was set as $\mathrm{p}<0.05$.

\section{RESULTS}

General features of participants and cellular phones they use are presented in Table 1.

All 631 cell phones investigated were contaminated with bacteria; forty-four of which were pathogenic microorganisms (Table 2) and the rest were skin flora bacteria. Drug resistance was not detected among pathogenic bacteria. Table 3 shows the variables and their association with pathogenic bacteria contamination. As determined by univariate analysis, using flip cover $(\mathrm{P}=0.022)$, a professional experience of fewer than five years $(\mathrm{P}=0.049)$, having cleaned the phone within the last 48 hours $(P=0.030)$, and working in a medical ward $(P=0.022)$ were significantly associated with pathogen contamination on the devices. Pathogen contamination on smartphones $(7.7 \%)$ seemed to be higher than on mobile phones (5.2\%). However, this difference was not statistically significant $(\mathrm{P}=$ 0.263). Multivariate analysis (Table 4) with logistic regression revealed that using flip cover (Figure 1 ) is the only factor associated with pathogen contamination on cell phones (OR:2.47; 95\%CI:1.075.73; $\mathrm{P}=0.035$ ) .

\section{DISCUSSION}

In the very first study on the incidence of bacterial contamination of cellular phones, Brady et al. reported evidence of bacterial contamination, of which nearly 15\% were known to cause HAIs. Based on the assumption that the use of cell phones in hospitals
Table 1. General Features of Participants ( $N=631)$

\begin{tabular}{|c|c|c|c|}
\hline Age & \multicolumn{3}{|l|}{34 Median $( \pm 9.32)$} \\
\hline Gender & \multicolumn{3}{|l|}{ Female 447 (70.8\%) } \\
\hline \multirow{3}{*}{$\begin{array}{l}\text { Professional } \\
\text { experience }\end{array}$} & Minimum & \multicolumn{2}{|c|}{1 month } \\
\hline & Maximum & \multicolumn{2}{|c|}{38 years } \\
\hline & Median & \multicolumn{2}{|c|}{9 years } \\
\hline \multirow{2}{*}{$\begin{array}{l}\text { Type of mobile } \\
\text { phone }\end{array}$} & Cellphone & 175 & $(27.7 \%)$ \\
\hline & Smartphone & 456 & $(72.2 \%)$ \\
\hline \multirow{6}{*}{ Occupation } & Faculty Member & 57 & $(9.06 \%)$ \\
\hline & Attending Physician & 117 & $(18.6 \%)$ \\
\hline & Resident & 36 & $(5.7 \%)$ \\
\hline & Nurse & 247 & $(39.2 \%)$ \\
\hline & Caregiver & 62 & $(9.8 \%)$ \\
\hline & Other & 112 & $(17.7 \%)$ \\
\hline \multirow{3}{*}{ Unit } & Internal Medicine & 355 & (56.3\%) \\
\hline & Surgery & 276 & $(43.7 \%)$ \\
\hline & Intensive Care & 108 & $(17.2 \%)$ \\
\hline
\end{tabular}

Table 2. Pathogenic bacteria isolated from mobile phones of the 631 HCWs

\begin{tabular}{|l|c|c|}
\hline Isolated bacteria & Count & $\%$ \\
\hline Staphylococcus aureus & 16 & 2.38 \\
\hline Acinetobacter baumannii & 9 & 1.42 \\
\hline Escherichia coli & 5 & 0.79 \\
\hline Pseudomonas aeruginosa & 4 & 0.63 \\
\hline Enterococcus spp. & 4 & 0.63 \\
\hline Providencia spp. & 2 & 0.32 \\
\hline Serratia spp. & 1 & 0.16 \\
\hline Other & 3 & 0.47 \\
\hline TOTAL & 44 & 6.05 \\
\hline
\end{tabular}


Table 3. Factors associated with pathogenic bacteria contamination (univariate analysis).

\begin{tabular}{|c|c|c|}
\hline Variable, count, (\%) & $\begin{array}{l}\text { Pathogenic bacteria } \\
\text { count, (\%) }\end{array}$ & $P$ value \\
\hline $\begin{array}{l}\text { Gender (woman) } \\
447,(70.8)\end{array}$ & $31,(6.9)$ & 0.953 \\
\hline $\begin{array}{l}\text { Physician } \\
268,(42.5)\end{array}$ & 19, (7.1) & 0.921 \\
\hline $\begin{array}{l}\text { Smartphone } \\
456,(72.3)\end{array}$ & $35,(7.7)$ & 0.263 \\
\hline $\begin{array}{l}\text { Single-sided cover usage } \\
342,(54.2)\end{array}$ & $28,(8.2)$ & 0.162 \\
\hline $\begin{array}{l}\text { Flip cover usage } \\
158,(25)\end{array}$ & $19,(12)$ & 0.022 \\
\hline $\begin{array}{l}\text { Carbon film usage } \\
293,(46.4)\end{array}$ & $25,(8.5)$ & 0.141 \\
\hline $\begin{array}{l}\text { Internal Medicine } \\
\text { Departments } \\
355,(56.2)\end{array}$ & $32,(9)$ & 0.022 \\
\hline $\begin{array}{l}\text { Working out of ICU } \\
523,(82.8)\end{array}$ & $41,(8)$ & 0.060 \\
\hline $\begin{array}{l}\text { Professional experience } \\
<5 \text { years } \\
385,(6)\end{array}$ & $33,(8.6)$ & 0.049 \\
\hline $\begin{array}{l}\text { Cleaning within the last } \\
48 \text { hours } \\
491,(78)\end{array}$ & $40,(8.2)$ & 0.030 \\
\hline $\begin{array}{l}\text { Duration of usage } \\
<30 \mathrm{dk} / \text { day } \\
238,(38)\end{array}$ & $19,(8)$ & 0.438 \\
\hline $\begin{array}{l}\text { Count of usage }<10 / \text { day } \\
266,(42.2)\end{array}$ & $19,(7.1)$ & 0.886 \\
\hline
\end{tabular}

may not be restricted, the authors recommended working on decontamination methods such as the use of alcohol disinfectant wipes in order to avoid cross-infection in healthcare settings (6). Indeed, several other studies documented that decontamination with alcohol reduced contamination (9-11). We did not evaluate the efficiency of decontamination. However, having cleaned the phone within the last 48 hours resulted
Table 4. Multivariate analysis of factors associated with pathogen contamination.

\begin{tabular}{|l|c|c|c|}
\hline Variables & $\begin{array}{c}\text { Odds } \\
\text { Ratio }\end{array}$ & P value & $\begin{array}{c}\text { [95\% } \\
\text { Confidence } \\
\text { Interval] }\end{array}$ \\
\hline $\begin{array}{l}\text { Cleaning cell phone } \\
\text { last 48 hours }\end{array}$ & 0.48 & 2.38 & $0.16-1.46$ \\
\hline $\begin{array}{l}\text { Working in a medical } \\
\text { ward }\end{array}$ & 0.76 & 1.42 & $0.33-1.80$ \\
\hline $\begin{array}{l}\text { Professional } \\
\text { experience }<5 \text { years }\end{array}$ & 0.53 & 0.79 & $0.22-1.32$ \\
\hline $\begin{array}{l}\text { Two-sided cover } \\
\text { usage }\end{array}$ & 2.47 & 6.05 & $1.07-5.73$ \\
\hline
\end{tabular}

in lower rates of contamination. As for medical devices, a specific decontamination procedure for cell phones seems inevitable in the near future, considering the extensive use of cell phones.

Suganya S. et al. (2012) reported that wiping the cell phones with 95\% ethanol and covering them with plastic cover reduced bacterial growth by nearly $90 \%$ (9). Their data is not comparable to ours since we evaluated the effect of the flip covers, which are protective for physical damage, and found that bacterial contamination was significantly higher in those cell phones (12.03\% vs. 5.08\%).

Previous studies reported a wide range of contamination rates $(8 \%-72 \%)$ of cell phones by pathogenic bacteria from different levels and units of health care facilities in Turkey $(8,12,13)$. Optimistically, somewhat lower contamination by pathogenic bacteria (6.05\%) in our study may be associated with elevated awareness based on previous experiences.

Only one study compared smartphones and mobile phones in terms of contamination (14). The authors reported that smartphones were more often contaminated by pathogenic bacteria than mobile phones (35\% vs. 20\%) because of larger surfaces and additional features. Although our initial hypothesis was along the same line, we did not observe a higher level of contamination in smartphones than mobile 
phones. Other differences -such as bacterial speciesexist among studies focusing on contamination through hands and cell phones. A study from India reported that there were no contamination with Gram-negative bacteria and Enterococcus on cellular phones of HCWs (15). The authors speculated that predominant colonization of Staphylococci on the hands of HCWs might have interfered with Gramnegative species. Although coagulase-negative Staphylococcus was the dominant bacteria on cell phones, we isolated Gram-negative bacteria such as E. coli, Acinetobacter, Pseudomonas, Serratia, Providencia. In our study, none of the pathogenic bacteria showed antimicrobial resistance while VRE, MRSA, and imipenem resistant Acinetobacter strains were identified by Loyala S. et al. (16).

One of our initial goals was to investigate crosscontamination between the cellular phone and the patient. According to the data collected by the infection control team, no HAIs related to the pathogens that we isolated from the cellular phones of the HCWs throughout this study occurred. However, without further investigation, it would be rather premature to assume that cellular phones are not associated with cross-contamination. Carefully structured further research should establish if such a link exists between cellular phone use and HAIs.

\section{CONCLUSION}

Using a flip phone cover is a significant risk factor for the contamination of HCW mobile phones. Although we could not show any HAI occurred by the bacteria isolated from cell phones, we do not recommend health care workers using flip covers.
Ethical Approval: This study was approved by Ankara University's Committee of Research, Ethics and Deontology.

Peer-review: Externally peer-reviewed

Author Contributions: Concept - D.Ö., S.B.A., Ç.Y., Ö.N., P.K., A.A.; Design - A.A., D.Ö., S.B.A., Ç.Y., Ö.N.; Supervision A.A., D.Ö.; Fundings - A.A.; Materials - D.Ö., S.B.A., Ç.Y., Ö.N., P.K.; Data Collection and/or Processing - D.Ö., S.B.A., Ç.Y., Ö.N., P.K.; Analysis and/or
Interpretation - D.Ö., S.B.A., Ç.Y., Ö.N., P.K.; Literature Review - D.Ö., S.B.A., Ç.Y., Ö.N., P.K.; Writer - .Ö., S.B.A., Ç.Y., Ö.N.; Critical Reviews - A.A.

Conflict of Interest: The authors have no conflict of interest to declare.

Financial Disclosure: The authors declared that this study has received no financial support.

\section{REFERENCES}

1 World Health Organization. The burden of health care-associated infection worldwide. Available from: URL: https://www. who.int/gpsc/country_work/burden_hcai/en/

2 Centers for Disease Control and Prevention. Healthcare-associated infections (HAIs). Available from: URL: https://www.cdc. gov/winnablebattles/report/HAIs.html

3 Centers for Disease Control and Prevention. Types of healthcare-associated infections. Available from: URL: https:// www.cdc.gov/hai/infectiontypes.html\#: :text=Infections\%20 can $\% 20$ be $\% 20$ associated $\% 20$ with, $\% 2$ C $\% 20$ and $\% 20$ ventilator\%2Dassociated\%20pneumonia

4 Qureshi NQ, Mufarrih SH, Irfan S, Rashid RH, Zubairi AJ, Sadruddin $\mathrm{A}$, et al. Mobile phones in the orthopedic operating room: microbial colonization and antimicrobial resistance. World J Orthop 2020; 11: 252-64.

5 Cavari Y, Kaplan O, Zander A, Hazan G, Shemer-Avni Y, Borer A. Healthcare workers mobile phone usage: a potential risk for viral contamination. Surveillance pilot study. Infect Dis (Lond) 2016; 48: 432-5.

6 Brady RRW, Wasson A, Stirling I, McAllister C, Damani NN. Is your phone bugged? The incidence of bacteria known to cause nosocomial infection on healthcare workers' mobile phones. J Hosp Infect 2006; 62: 123-5.

7 Martina PF, Martinez M, Centeno CK, M VONS, Ferreras J. Dangerous passengers: multidrug-resistant bacteria on hands and mobile phones. J Prev Med Hyg 2019; 60: E293-E299.

8 Ulger F, Esen S, Dilek A, Yanik K, Gunaydin M, Leblebicioglu H. Are we aware how contaminated our mobile phones with nosocomial pathogens? Ann Clin Microb Anti 2009; 8: 7.

9 Suganya S, Sumathy JHV. Isolation and identification of bacteria from covered and uncovered mobile phones. Int J Environ Sci 2012; 3: 44-54.

10 Sadat-Ali M, Al-Omran AK, Azam Q Bukari H, Al-Zahrani AJ, Al-Turki RA, et al. Bacterial flora on cell phones of health 
care providers in a teaching institution. Am J Infect Control 2010;38: 404-5.

11 Singh S, Acharya S, Bhat M, Rao SK, Pentapati KC. Mobile phone hygiene: potential risks posed by use in the clinics of an Indian dental school. J Dent Educ 2010; 74: 1153-8.

12 Kilic IH, Ozaslan M, Karagoz ID, Zer Y, Davutoglu V. The microbial colonisation of mobile phone used by healthcare staffs Pak J Biol Sci 2009; 12: 882-4.

13 Ustun C, Cihangiroglu M. Health care workers' mobile phones: a potential cause of microbial cross-contamination between hospitals and community. J Occup Environ Hyg 2012;9: 538-42.
14 Lee YJ, Yoo CG, Lee CT, Chung HS, Kim YW, Han SK, et al. Contamination rates between smart cell phones and non-smart cell phones of healthcare workers. J Hosp Med 2013; 8: 144-7.

15 Datta P, Rani H, Chander J, Gupta V. Bacterial contamination of mobile phones of health care workers. Indian J Med Microbiol 2009; 27: 279-81.

16 Loyola S, Gutierrez L, Avendano E, Severino N, Tamariz J. Multidrug-resistant bacteria isolated from cell phones in five intensive care units: Exploratory dispersion analysis. Germs. 2018; 8: 85-91. 